\title{
DAMPAK KEBIJAKAN KEMASAN ROKOK SINGAPURA TERHADAP EKSPOR ROKOK INDONESIA
}

\section{The Impact of Singapore's Cigarette Plain Packaging Policy on the Exports of Indonesian Cigarettes}

\author{
Aditya P. Alhayat \\ Pusat Kebijakan Perdagangan Luar Negeri, BPPKP, Kementerian Perdagangan RI, \\ JI. MI Ridwan Rais No. 5, Jakarta Pusat, 10110, \\ email : aditya.alhayat@kemendag.go.id
}

Naskah diterima: 18/08/2015 Naskah direvisi: 29/10/2015 Disetujui diterbitkan: 26/11/2015

\begin{abstract}
Abstrak
Pemerintah Singapura telah melakukan beragam kebijakan pengendalian tembakau (tobacco control) untuk menekan jumlah perokok. Singapura termasuk salah satu negara di dunia yang menerapkan regulasi ketat dalam pengendalian produk tembakau. Penelitian ini bertujuan untuk memperkirakan dampak penerapan kebijakan kemasan rokok Singapura terhadap ekspor rokok Indonesia. Kebijakan tersebut diasumsikan memiliki dampak sebagaimana kebijakan pengendalian konsumsi tembakau non-harga pada umumnya meskipun kebijakan tersebut belum diimplementasikan. Metode yang digunakan berupa analisis deskriptif yang dilengkapi dengan analisis ekonometri menggunakan Two-Stage Least Squares (2SLS) dengan sampel Triwulan III-2006 hingga Triwulan IV-2014. Hasil analisis menunjukkan bahwa ekspor rokok Indonesia lebih dipengaruhi oleh re-ekspor Singapura dibandingkan dengan konsumsi domestiknya. Selain itu, kebijakan pengendalian tembakau non-harga secara statistik tidak berpengaruh terhadap konsumsi rokok di Singapura. Oleh sebab itu, Indonesia tidak perlu terlalu khawatir dengan rencana kebijakan kemasan rokok yang akan diterapkan. Pemerintah Indonesia harus aktif melakukan negosiasi apabila Singapura benar-benar menerapkan kebijakan kemasan rokok dalam rangka mendapatkan kompensasi perdagangan atas kebijakan tersebut.
\end{abstract}

Kata Kunci: Kebijakan Kemasan, Permintaan Ekspor, Konsumsi Rokok, 2SLS

\begin{abstract}
The government of Singapore has implemented various tobacco control policies to reduce the number of smoker. Singapore is one of the countries in the world that implemented a tight regulation to control tobacco products. This study aims to estimate the potential impacts of Singapore's cigarette plain packaging policy on the Indonesian cigarettes exports. As this policy is not yet implemented, it is assumed that the policy will have the same impacts as the common tobacco control policy, especially for the non-price policy. The study used descriptive analysis supported by econometrics analysis using Two-Stage Least Squares method (2SLS) using quarterly data from III-2006 to IV-2014. The results showed that the Indonesian cigarettes export is much more influenced by the Singapore's re-exports rather than by the domestic consumption. Moreover, the non-price tobacco control policies do not have statistically significant effect on the cigarette consumption in Singapore. Therefore, Indonesia should not be worried about the possible implementation of the plain packaging policy. Indonesian government must actively negotiate if Singapore finally implements the plain packaging policy to get a compensation trade from this policy.
\end{abstract}

Keywords: Plain Packaging, Exports Demand, Cigarettes Consumption, 2SLS

JEL Classification: D12, F10, F14 


\section{PENDAHULUAN}

Pada bulan Maret 2015, Pemerintah Singapura mengumumkan akan menyelenggarakan konsultasi publik (public hearing) hingga akhir tahun 2015 terkait rencana amandemen terhadap The Tobacco (Control of Advertisements and Sale) Act (TCASA) tahun 2003 sebagaimana terakhir kali diamandemen tahun 2010. Ketentuan kemasan rokok dan produk tembakau lainnya (plain packaging) merupakan salah satu hal yang ingin dimasukkan dalam amandemen TCASA di tahun 2015 dengan tujuan utama untuk mengurangi daya tarik rokok dan produk tembakau serta meningkatkan tingkat visibilitas peringatan kesehatan (MOH, 2015). Secara spesifik, amandemen tersebut berisi penghapusan seluruh aspek promosi pada kemasan tembakau (hak cipta, logo, skema warna, dan imagery); adanya kebijakan kemasan dalam hal ukuran huruf dan peletakan teks; serta tetap mempertahankan kewajiban pencantuman peringatan kesehatan.

Sebelum rencana implementasi kebijakan baru tersebut, Pemerintah Singapura telah melakukan beragam kebijakan tobacco control untuk menekan jumlah perokok. Bahkan, Singapura termasuk dalam salah satu negara di dunia yang menerapkan regulasi ketat dalam pengendalian produk tembakau. Terdapat berapa tonggak penting kebijakan pemerintah Singapura untuk mengendalikan produk tembakau yang telah dimulai sejak tahun 1970 dengan menerapkan larangan merokok di tempat umum (MOH, 2015). Pada tahun 1971, Singapura mencatatkan sebagai negara pertama di kawasan Asia yang melarang iklan produk tembakau. Kemudian pada Agustus 2004, Singapura menjadi negara pertama di Asia yang mensyaratkan agar seluruh kemasan produk tembakau memiliki label peringatan kesehatan (gambar dan teks) dalam rangka mengingatkan perokok mengenai dampak negatif konsumsi rokok. Pada Januari 2009, Singapura menjadi negara pertama di dunia yang mewajibkan pemberian label "SDPC" pada setiap batang rokok yang telah membayar cukai. Pelarangan istilah pada kemasan rokok yang dapat disalahartikan (misleading desciptor), misalnya "mild" dan "light" serta menurunkan tingkat kandungan tar dan nikotin yang diizinkan dilakukan pada Maret 2013. Mulai awal tahun 2014, Pemerintah Singapura menaikan cukai rokok sebesar $10 \%$ sehingga menjadi USD 388 per $\mathrm{kg}$ atau 38,8 sen per gram untuk setiap batang rokok. Sebelumnya, cukai rokok adalah sebesar USD 352 per kg selama periode 2005-2013 dan sebesar USD 293 per kg di tahun 2004. Pada November 2014, Singapura melarang shisha karena dianggap sama berbahayanya dengan produk tembakau lainnya. Namun demikian, importir dan pengecer yang memiliki lisensi masih diperkenankan melakukan importasi maupun menjual shisha hingga 31 Juli 2016. 
Bagi Indonesia, Singapura merupakan salah satu negara tujuan utama ekspor produk rokok selain Kamboja, dan Malaysia. Selama periode 2005-2014, ketiga negara tersebut menyumbang rata-rata sebesar $75 \%$ dari total nilai ekspor rokok Indonesia ke dunia ${ }^{1}$. Kamboja merupakan tujuan ekspor utama rokok Indonesia dengan pangsa 30,0\% tahun 2005 dan meningkat menjadi $37,2 \%$ tahun 2015 . Singapura pada tahun 2015 merupakan tujuan ekspor rokok kedua terbesar Indonesia dengan pangsa $25,8 \%$, namun pada lima tahun terakhir pangsanya hanya mencapai $14 \%$ digantikan oleh peran Malaysia yang semakin besar melakukan impor rokok dari Indonesia (BPS, 2015a).

Meskipun pangsa ekspor rokok ke Singapura cenderung menurun, namun Singapura masih merupakan negara tujuan ekspor yang penting. Segala jenis hambatan perdagangan dan akses pasar ke Singapura berpotensi menurunkan ekspor rokok Indonesia khususnya dan ekspor Indonesia pada umumnya. Oleh karena itu, tulisan ini berupaya untuk memberikan gambaran potensi dampak kebijakan plain packaging Singapura terhadap ekspor Indonesia. Benarkah plain packaging akan secara efektif mengurangi konsumsi rokok Singapura dan juga mengurangi jumlah impor rokok Singapura dari Indonesia? Dalam hal ini, potensi dampak kebijakan plain packaging diproksi dengan kebijakan tobacco control Singapura yang telah dilakukan sebelumnya. Apabila kebijakan tobacco control Singapura khususnya terkait kebijakan non-harga berpengaruh negatif terhadap konsumsi rokok, maka kebijakan plain packaging diekspektasikan memiliki efek yang serupa jika diimplementasikan oleh Pemerintah Singapura.

Istilah plain packaging mulai populer ketika pemerintah Australia di tahun 2012 mengeluarkan suatu peraturan yang salah satu poin pentingnya adalah mensyaratkan semua produk tembakau yang dijual (secara legal) di Australia dikemas dalam suatu kemasan yang standar (Davidson \& de Silva, 2014). Selain Singapura, beberapa negara lain seperti Inggris, Irlandia, dan Selandia Barutelah menginisiasikebijakan serupa. Dengan kemasan yang standar, semua produk tembakau akan tampak homogen karena tidak lagi mencantumkan seluruh merek dagang (warna, logo, dan sebagainya). Selain menampilkan label peringatan kesehatan, produsen rokok hanya diizinkan menulis nama merek menggunakan bentuk dan ukuran huruf tertentu pada suatu bagian pada kemasan yang telah ditetapkan dengan warna kemasan yang juga seragam.

Produk rokok didefinisikan ke dalam HS 2402 (cerutu, cheroot, cerutu kecil dan sigaret, dari tembakau atau pengganti tembakau). 


\section{METODE}

Kebijakan plain packaging Singapura masih dalam proses dan belum diterapkan sehingga data riil akibat kebijakan tersebut belum tersedia. Oleh karena itu, potensi dampak kebijakan plain packaging terlebih dahulu akan dianalisis dengan menggunakan analisis deskriptif berdasarkan datadata sekunder dan penelitian yang relevan. Fokus utama analisis ini adalah untuk melihat apakah kebijakan tobacco control yang telah dilakukan Singapura berpengaruh terhadap kinerja ekspor rokok Indonesia serta bagaimana peruntukan impor rokok oleh Singapura (apakah dikonsumsi dalam negeri ataukah diekspor kembali ke negara lain).

Analisis selanjutnya dilakukan dengan menggunakan metode ekonometrik, yaitu Two-Stage Least Squares (2SLS) dengan sampel Triwulan III-2006 hingga Triwulan IV-2014². Dalam hal ini, kebijakan plain packaging diasumsikan sama dengan kebijakan-kebijakan pengendalian konsumsi rokok non-harga yang telah dikeluarkan oleh Pemerintah Singapura pada periode tersebut. Apabila kebijakan non-harga secara statistik berpengaruh negatif terhadap konsumsi rokok Singapura, maka kebijakan plain packaging diperkirakan juga memiliki dampak yang sama. Pengurangan konsumsi rokok selanjutnya akan berdampak pada penurunan ekspor rokok Indonesia ke Singapura.

Metode 2SLS diperlukan karena kebijakan pengendalian konsumsi rokok diasumsikan berpengaruh tidak langsung terhadap impor rokok Singapura (pengaruh langsung melalui konsumsi rokok domestik terlebih dahulu) $)^{3}$. Secara konseptual, fungsi persamaan 2SLS yang digunakan terdiri dari fungsi konsumsi rokok di Singapura (Persamaan 1) yang kemudian dijadikan sebagai instrumental variabel dalam fungsi ekspor rokok Indonesia ke Singapura (Persamaan 2). Adapun penjelasan ringkas masingmasing variabel beserta data yang digunakan dapat dilihat pada Tabel 1.

Cons $=f\left(\right.$ Inc $, P, E x c$, GST, Cons $_{\mathrm{t}-1}$, Cons $_{\mathrm{t}+}$ ${ }_{1}$, SmRes, NonRes, Dtco)

Xind $=f($ Cons $, X \sin , R E E R, D c r i s) .$.

Sampel penelitian yang digunakan merupakan data kuartalan dengan memanfaatkan data sekunder yang ada, diantaranya dari Badan Pusat Statistik (BPS), CEIC Global Database, dan Global Trade International Services (GTIS). Dikarenakan data yang digunakan adalah data kuartalan, maka dilakukan beberapa penyesuaian, yaitu kurs, pendapatan, dan harga

2 Pada mulanya digunakan sampel periode 2004-2014. Namun, karena terdapat beberapa outlier data untuk periode Triwulan I-2004 hingga Triwulan II-2006 sehingga tidak dimasukkan sebagai sampel pada estimasi metode ekonometrik.

3 Metode 2SLS merupakan metode yang umum digunakan untuk mengestimasi parameter-parameter pada suatu persamaan struktural yang diidentifikasi (Hill, Griffiths, dan Lim, 2012: pp. 252) 
rokok bulanan dijadikan data kuartalan dengan menggunakan rata-rata pada periode bersangkutan. Sementara itu, data perdagangan dan kuantitas rokok yang telah dibayarkan cukainya diubah menjadi data kuartalan dengan menjumlahkan pada kuartal yang bersesuaian. Variabel konsumsi rokok seharusnya menggunakan jumlah batang rokok yang dikonsumsi secara riil (baik legal maupun illegal), namun karena data tersebut hanya tersedia pada tahun tertentu (tidak tersedia dalam series bulanan atau kuartalan),

Tabel 1. Variabel-variabel yang Digunakan pada Analisis Ekonometrik

\begin{tabular}{|c|c|c|c|}
\hline Variabel & Keterangan & Data yang Digunakan & Sumber Data \\
\hline Xind & $\begin{array}{l}\text { Volume ekspor rokok } \\
\text { Indonesia ke Singapura }\end{array}$ & Volume ekspor HS 2402 (Ton) & BPS \\
\hline Cons & $\begin{array}{l}\text { Jumlah konsumsi rokok } \\
\text { Singapura } \\
\text { Volume ekspor rokok }\end{array}$ & $\begin{array}{l}\text { Duty Paid Releases of Cigarette (Ton). } \\
\text { Data Q2-2010 hingga Q4-2014 diestimasi } \\
\text { dengan Duty Paid Releases of Tobacco }\end{array}$ & CEIC \\
\hline$X \sin$ & $\begin{array}{l}\text { Singapura ke Dunia (proksi } \\
\text { reekspor) }\end{array}$ & Volume ekspor HS 2402 (Ton) & GTIS \\
\hline REER & Nilai tukar riil & Nilai tukar riil Rupiah & BIS \\
\hline Dcris & $\begin{array}{l}\text { Dummy krisis perekonomian } \\
\text { dunia }\end{array}$ & $\begin{array}{l}\text { Dcris=1 (Q3-2008 s.d. Q4-2009); lainnya } \\
\text { Dcris=0 }\end{array}$ & - \\
\hline Inc & $\begin{array}{l}\text { Pendapatan riil penduduk } \\
\text { Singapura }\end{array}$ & $\begin{array}{l}\text { Rata-rata Pendapatan bulanan (SGD) } \\
\text { yang disesuaikan terhadap harga umum } \\
\text { konsumen (CPI) }\end{array}$ & CEIC \\
\hline $\mathrm{P}$ & Harga riil rokok di Singapura & $\begin{array}{l}\text { Harga ritel rokok (SGD/paket) yang } \\
\text { disesuaikan terhadap harga umum } \\
\text { konsumen (CPI) }\end{array}$ & $\begin{array}{l}\text { CEIC } \\
\text { Ministry of }\end{array}$ \\
\hline Exc & Cukai rokok & Cukai rokok (SGD per kg) & $\begin{array}{l}\text { Finance, } \\
\text { Singapore } \\
\text { Ministry of }\end{array}$ \\
\hline GST & Global Service and Tax & $\begin{array}{l}\text { GST }(\% \text { ad valorem }) \\
\text { Dtco }=1 \text { periode setelah pemerintah }\end{array}$ & $\begin{array}{l}\text { Finance, } \\
\text { Singapore }\end{array}$ \\
\hline Dtco & $\begin{array}{l}\text { Dummy kebijakan tobacco } \\
\text { control Singapura }\end{array}$ & Son-harga untuk menekan konsumsi produk & $\begin{array}{l}\text { Ministry } \\
\text { of Health, } \\
\text { Singapore }\end{array}$ \\
\hline SmRes & Jumlah warga yang merokok & $\begin{array}{l}\text { Diestimasi dengan smoking prevalence dari } \\
\text { hasil National Health Surveillance Survey }\end{array}$ & $\begin{array}{l}\text { Ministry } \\
\text { of Health, } \\
\text { Singapore, CEIC }\end{array}$ \\
\hline NonRes & Jumlah imigran & Jumlah orang yang menetap sementara & $\begin{array}{l}\text { Statistics } \\
\text { Singapore }\end{array}$ \\
\hline
\end{tabular}


maka variabel konsumsi diproksi dengan jumlah rokok yang telah dibayarkan cukainya ${ }^{4}$.

Kedua fungsi yang digunakan dalam metode 2SLS pada dasarnya merupakan fungsi permintaan/konsumsi sebagaimana teori konsumsi pada umumnya. Konsumsi rokok di Singapura diharapkan dipengaruhi secara positif oleh pendapatan masyarakat dan berkorelasi negatif dengan harga rokok. Kebijakan cukai rokok dan Global Service and Tax (GST) diharapkan menurunkan jumlah konsumsi rokok sehingga koefisien bernilai negatif. Sementara itu, kebijakan tobacco control non-harga juga diharapkan mengurangi konsumsi rokok, sebagaimana tujuan kebijakan yang ingin dicapai oleh pengambil kebijakan sehingga koefisien Dtco diharapkan bertanda negatif. Sesuai dengan sampel yang diambil, kebijakan non-harga yang dimasukkan dalam analisis adalah kewajiban label SDPC (D_label) dan pelarangan misleading descriptor (D_misdesc).

Hal spesifik terkait fungsi konsumsi rokok adalah elastisitas harga permintaan rokok tergolong rendah (inelastis). Artinya, meskipun harga rokok dinaikkan, konsumen tetap terus merokok pada jumlah yang relatif sama. Hal ini dikarenakan merokok merupakan salah satu bentuk kecanduan sehingga perokoktidakmudahuntukmenghentikan kebiasaannya tersebut (Forbes, 2013 dan Business World, 2013). Scollo \& Winstanley (2012) menyebutkan bahwa teori permintaan rokok pada umumnya mengacu pada myopic addiction model. Teori ini memperkirakan bahwa faktorfaktor seperti harga dan pendapatan akan mempengaruhi tingkat konsumsi rokok. Namun demikian, apabila pola konsumsi telah berada pada kategori kecanduan maka konsumen/individu cenderung untuk mengabaikan biayabiaya masa depan (finansial maupun kesehatan). Dengan demikian, penurunan harga akan meningkatkan konsumsi dan sebaliknya peningkatan harga akan menurunkan konsumsi, namun dampak peningkatan harga tersebut lebih rendah dibandingkan dengan dampak penurunan harga.

Sebaliknya, rational addiction model menolak dalil bahwa perokok berperilaku secaramyopic. Modelinimengasumsikan bahwa perokok juga melakukan pilihan rasional, mempertimbangkan antara nikmatnya rokok saat ini dan tidak nikmatnya berhenti merokok serta antara dampak negatif/biaya konsumsi rokok dan dampak kesehatan jangka panjang. Becker \& Murphy (1988) serta Becker, Grossman, \& Murphy (1994) telah mendemonstrasikan betapa pentingnya hubungan antar waktu pada permintaan rokok yang mendukung dalil perilaku adiktif rasional. Oleh karena itu, penelitian ini memasukkan variabel konsumsi masa lalu (Cons $\left.s_{t-1}\right)$ dan konsumsi masa depan ( Cons $_{t+1}$ ) untuk menguji apakah permintaan rokok di Singapura mengikuti myopic atau rational addictive behavior. Sebagaimana

$4 \quad$ Czubek dan Johal (2010) menggunakan jumlah batang rokok yang telah dibayarkan cukainya per kapita sebagai variabel dependen persamaan permintaan rokok di Inggris, sedangkan Chaloupka dan Tauras (2011) menggunakan pembayaran cukai penjualan rokok sebagai variabel dependen untuk mengestimasi permintaan rokok di Irlandia. 
diungkapkan oleh Chaloupka (1991), apabila merokok merupakan perilaku adiktif, maka seharusnya tidak ada dampak konsumsi masa lalu atau masa depan terhadap konsumsi saat ini. Sementera itu, jika merokok merupakan perilaku adiktif namun individu bersikap secara myopic, maka konsumsi masa lalu seharusnya memiliki dampak positif terhadap konsumsi saat ini, namun tidak berdampak pada konsumsi masa depan ${ }^{5}$.

Hasil studi empiris World Bank (1999) menyimpulkan bahwa dengan mengasumsikan faktor-faktor lain konstan, peningkatan harga 10\% dapat mengurangi rata-rata konsumsi tembakau/rokok sebesar $4 \%$ di negara maju dan $8 \%$ di negara berkembang. Sementara itu, Gallet \& List (2003) dengan menggunakan metode metaanalisis menyimpulkan bahwa elastisitas harga untuk permintaan rokok adalah $-0,48$ yang artinya bahwa peningkatan harga sebesar $10 \%$ akan mendorong penurunan konsumsi rokok sebesar $4,8 \%$.

International Agency for Research on Cancer/IARC (2011) juga melakukan studi dampak peningkatan harga pada permintaan agregat produk tembakau di negara berpendapatan tinggi dimana hasil studi menunjukkan elastisitas harga sebesar-0,4. Hasil yang serupa diperoleh Nguyen, Rosenqvist, \& Pekurinen (2012) dengan elastisitas harga rokok di Eropa berkisar $-0,30$ hingga $-0,40$. Penelitian Chen \& Xing (2011) dan Liu et al. (2015) memperoleh angka elastisitas harga rokok tertinggi di China sebesar $-0,81$. Sementara itu, elastisitas harga jangka panjang permintaan rokok di Pakistan mencapai -1,17 (Mushtaq, Mushtaq, \& Beebe, 2011). Hasil studi empiris di atas setidaknya menunjukkan bahwa kenaikan harga rokok berpengaruh lebih besar terhadap pengurangan konsumsi rokok di negara berkembang dibandingkan dengan di negara maju.

Fungsi permintaan ekspor rokok Indonesia ditujukan untuk mengetahui seberapa signifikan dan besarnya pengaruh konsumsi rokok di Singapura maupun re-ekspor rokok yang dilakukan Singapura. Kemungkinan bahwa rokok yang diimpor oleh Singapura dari Indonesia diekspor kembali ke negara-negara lain adalah sangat besar mengingat Singapura merupakan salah satu hub perdagangan terbesar di kawasan Asia Tenggara. Secara hipotesis, konsumsi rokok maupun reekspor Singapura berpengaruh positif terhadap ekspor rokok Indonesia. Sementara itu, dummy Dcris digunakan untuk mengontrol kemungkinan pengaruh negatif dari krisis perekonomian dunia termasuk Singapura yang terjadi di tahun 2008-2009.

\section{HASIL DAN PEMBAHASAN}

\section{Kinerja Ekspor Rokok Indonesia dan Kebijakan Tobacco Contro/Singapura}

Meskipun Singapura telah mengatur konsumsi rokok secara ketat, namun ekspor rokok Indonesia ke Singapura terus mengalami peningkatan. Pada tahun 2004, nilai ekspor rokok Indonesia ke Singapura mencapai USD 42,3 juta,

5 Studi empiris Hidayat dan Thabrany (2011) mengenai permintaan rokok di Indonesia menyimpulkan bahwa rokok termasuk barang adiktif dan perokok berperilaku secara myopic serta menolak hipotesis adiktif rasional. 
kemudian meningkat menjadi USD 66,6 juta (2010) dan USD 109,8 juta (2014). Dari sisi volume, ekspor rokok Indonesia ke Singapura juga mengalami peningkatan dari 4,8 ribu ton di tahun 2004 menjadi 9,1 ribu ton di tahun 2014 (BPS, 2015a).

Semua barang yang akan dikonsumsi di Singapura dikenakan GST yang saat ini besarnya $7 \%$. GST diperkenalkan pada 1 April 1994 dengan pungutan sebesar $3 \%$. GST dinaikkan menjadi 4\% pada tahun 2003 dan menjadi $5 \%$ pada tahun 2004 . Terakhir, GST dinaikkan menjadi $7 \%$ sejak 1 Juli 2007 (MOF, 2015). Untuk semua produk rokok dikenakan tarif impor sebesar nol dan dipungut cukai sesuai dengan jenis produknya yang (umumnya sebesar USD 388 per kg).

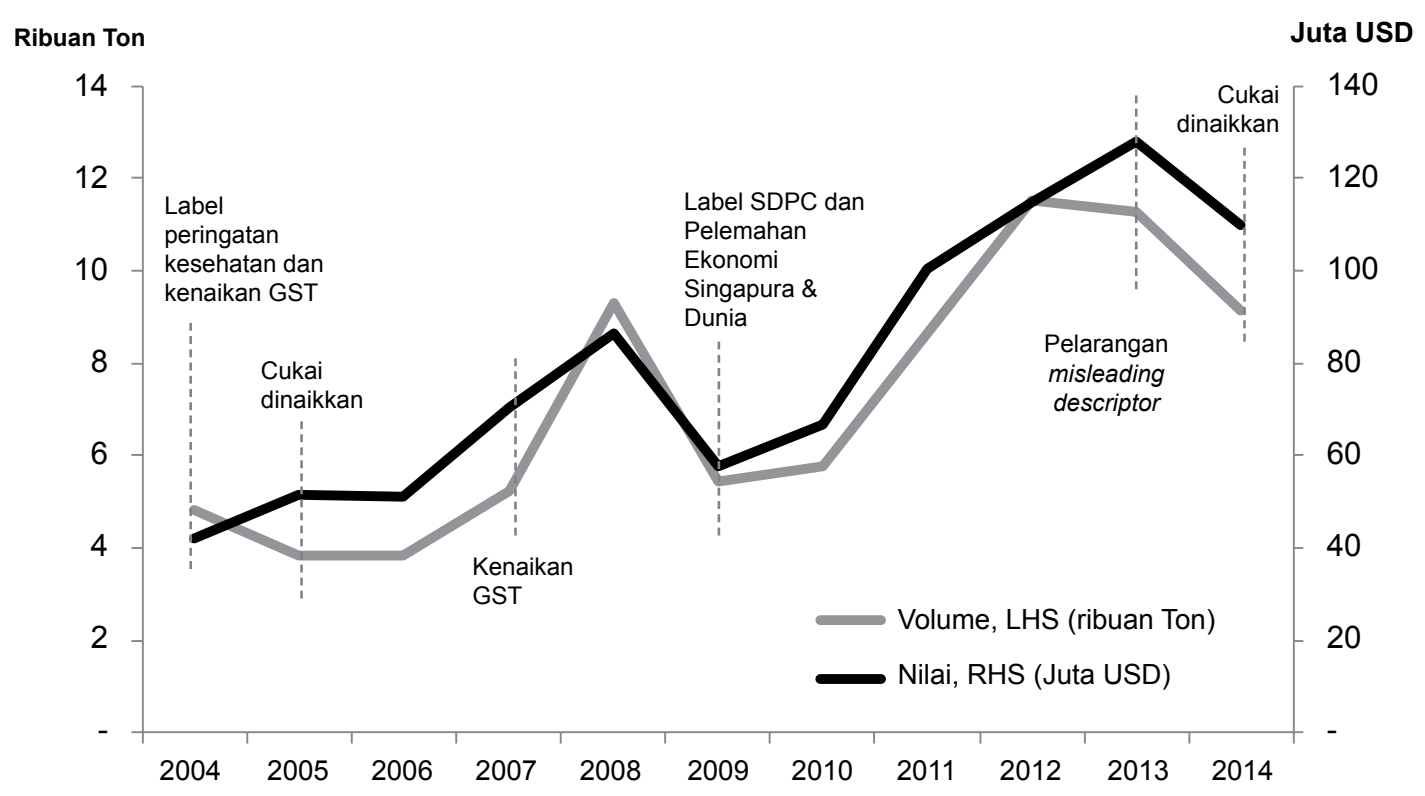

\section{Gambar 1. Ekspor Rokok Indonesia ke Singapura dan Kebijakan Tobacco Control Singapura}

Sumber: BPS (2015a) dan MOH (2015), diolah

Secara sederhana, kita dapat mengetahui faktor apa saja yang mempengaruhi kinerja ekspor rokok Indonesia ke Singapura dengan membandingkan pergerakan nilai/ volume ekspor Indonesia dengan kebijakan pengendalian rokok Singapura atau kondisi perekonomian domestiknya. Dalam hal ini, faktor ekonomi seperti harga (cukai) dan pendapatan masyarakat (pertumbuhan ekonomi) di pasar ekspor lebih berdampak terhadap ekspor Indonesia dibandingkan dengan faktor non ekonomi (regulasi). Penurunan volume ekspor rokok Indonesia ke Singapura terjadi di tahun 2005, namun nilai ekspornya tetap meningkat. Penurunan volume lebih disebabkan adanya kenaikan cukai rokok pada tahun tersebut. Kemudian, 
terjadi penurunan signifikan ekspor rokok Indonesia ke Singapura di tahun 2009 baik dari sisi nilai maupun volume karena melemahnya perekonomian Singapura dan dunia secara umum. Sementara itu, ekspor rokok di tahun 2014 juga menurun yang diduga kuat karena kombinasi dampak kenaikan cukai rokok dan melemahnya ekonomi Singapura di tahun tersebut. Dengan demikian, patut diduga bahwa volume ekspor rokok Indonesia ke Singapura setidaknya dipengaruhi oleh kebijakan cukai di Singapura dan kondisi perekonomian dimestiknya. Selain itu, kebijakan tobacco control khususnya plain packaging diperkirakan akan berdampak negatif terhadap ekspor rokok Indonesia ke Singapura.

\section{Jalur Distribusi Produk Rokok Indonesia di Singapura}

Secara umum, terdapat tiga jalur masuknya rokok Indonesia di Singapura. Pertama, rokok Indonesia masuk ke pasar Singapura melalui jaringan perusahaan rokok multinasional. Kedua, rokok Indonesia dikirim ke Singapura untuk diekspor kembali (re-ekspor) ke negara lainnya. Ketiga, rokok Indonesia diselundupkan masuk ke pasar Singapura. Dari ketiga jalur tersebut, reekspor rokok Indonesia oleh Singapura merupakan yang paling dominan.

Penjualan rokok domestik di Singapura didominasi oleh tiga produsen rokok multinasional yaitu British American Tobacco (BAT), Japan Tobacco International (JTI), dan Philip Morris International (PMI). Ketiga perusahaan tersebut memiliki pangsa pasar lebih dari $90 \%$ penjualan rokok yang legal (International Tax and Investment Center \& Oxfords Economics, 2014). Secara lebih terperinci, Assunta dan Chapman (2004) menyebutkan bahwa PMI menguasai pasar rokok terbesar di Singapura (50\%), diikuti oleh BAT (31\%) dan JTI (17\%). Hal yang menarik adalah Singapura tidak lagi memproduksi rokok sejak tahun 1990 dan hanya memiliki 6 hektar lahan untuk tanaman tembakau dengan produksi daun tembakau 10 ton di tahun tersebut. Selanjutnya sejak tahun 2000, Singapura tidak lagi memiliki lahan untuk menanam tembakau (WHO, 2015). Ketiga produsen rokok multinasional tersebut memiliki perwakilan bisnis di Singapura, namun produksinya dilakukan di luar Singapura. PMI memiliki pabrik rokok di Indonesia setelah mengakuisisi PT HM Sampoerna Tbk tahun 2005 (PMI, 2005), sedangkan BAT mengakuisisi perusahaan rokok nasional Indonesia PT Bentoel Internasional Investama Tbk tahun 2009 (BAT, 2009). Sementara itu, JTI tidak memiliki jaringan produksi di Indonesia namun memiliki pabrik besar di Rusia (JTI, 2015).

Ada indikasi kuat bahwa Singapura melakukan re-ekspor produk rokok Indonesia. Hal ini dikarenakan Singapura tidak memiliki industri rokok namun mampu melakukan ekspor rokok, bahkan neraca perdagangan Singapura untuk produk rokok mengalami surplus. Pada periode Januari-Mei 2015, surplus perdagangan rokok Singapura mencapai USD 210,7 juta, hampir menyamai pencapaian surplus tahun 2014 yang mencapai USD 234,4 juta (Tabel 2). 
Tren ekspor rokok Singapura untuk periode 2010-2014 meningkat 13,8\% per tahun, melebihi tren impornya yang sebesar 9,4\% per tahun. Khusus untuk rokok kretek/cengkeh (HS 24022020), Singapura melakukan impor dari Indonesia sebanyak 4.219 ton di tahun 2014 dan melakukan ekspor ke dunia di tahun tersebut sebesar 4.086 ton. Hal tersebut mengindikasikan bahwa Singapura melakukan re-ekspor hampir keseluruhan rokok kretek impor dari Indonesia dan Singapura bukan merupakan pasar akhir produk rokok Indonesia.

Tabel 2. Perkembangan Perdagangan Rokok Singapura dengan Dunia (USD Juta)

\begin{tabular}{|c|c|c|c|c|c|c|c|}
\hline \multirow{2}{*}{ Keterangan } & \multirow{2}{*}{2010} & \multirow{2}{*}{2012} & \multirow{2}{*}{2014} & \multicolumn{2}{|c|}{ Jan-Mei } & \multirow{2}{*}{$\begin{array}{c}\text { Perub. (\%) } \\
2015 / 14\end{array}$} & \multirow{2}{*}{$\begin{array}{c}\text { Trend }(\%) \\
2010-14\end{array}$} \\
\hline & & & & 2014 & 2014 & & \\
\hline Ekspor & 537,2 & 762,2 & 920,7 & 366,9 & 487,8 & 32,9 & 13,8 \\
\hline Impor & 472,5 & 630,5 & 686,3 & 279,5 & 277,1 & $-0,9$ & 9,4 \\
\hline Neraca & 64,8 & 131,9 & 234,4 & 87,5 & 210,7 & 140,9 & 36,5 \\
\hline
\end{tabular}

Sumber: GTIS (2015a), diolah

Larangan iklan, promosi, dan sponsorships terkait produk tembakau di Singapura telah diatur dalam The Tobacco (Control of Advertisements and Sale) Act (TCASA). Ketentuan tersebut juga mengatur pengendalian penggunaan dan penjualan produk tembakau bagi kalangan muda, serta mengatur label dan peringatan kesehatan. Namun demikian, ketentuan importasi produk tembakau/rokok di Singapura tidak perlu mengikuti TCASA apabila produk tersebut ditujukan untuk dijual kembali ke luar Singapura (untuk keperluan re-ekspor dan bukan untuk konsumsi domestik).

Berdasarkan data dari International Tax and Investment Center dan Oxford Economics (2014), jumlah konsumsi rokok (legal dan ilegal) di Singapura diperkirakan 3,4 miliar batang rokok pada tahun 2013 , turun $3,4 \%$ dari tahun 2012. Dari jumlah tersebut, sekitar $80,4 \%$ atau 2,7 miliar batang rokok merupakan konsumsi domestik yang legal. Sisanya $19,6 \%$ atau 0,7 miliar batang rokok merupakan konsumsi yang ilegal. Pasar rokok ilegal di Singapura seluruhnya merupakan produk contraband yaitu rokok yang sengaja diselundupkan masuk ke Singapura tanpa pembayaran pajak dan bea yang berlaku (rokok selundupan). Dalam hal ini, Indonesia dan Malaysia merupakan negara utama asal rokok ilegal, masingmasing sebesar $66 \%$ dan $25 \%$ dari total konsumsi rokok ilegal. 


\section{Pengalaman Indonesia terhadap Kebijakan Rokok yang Telah Diterapkan di Negara-negara Tujuan Ekspor Indonesia}

\section{Amerika Serikat: Tobacco Control Act}

Pada tanggal 22 Juni 2009, Pemerintah AS secara resmi mengeluarkan peraturan "Family Smoking Prevention Tobacco Control Act of 2009" yang pada dasarnya mengatur produksi, distribusi, dan pemasaran produk-produk tembakau. Peraturan tersebut diantaranya berisi pembatasan pemasaran dan penjualan tembakau pada penduduk usia muda, kewajiban pencantuman label peringatan pada produk tembakau tanpa asap, serta pencantuman kandungan pada produk tembakau (US FDA, 2015). Secara khusus, poin 907 pada Tobacco Control Act mengatur larangan penggunaan rokok yang mengandung rasa (flavored cigarettes), kecuali terhadap rokok mentol (US GPO, 2009). Ketentuan tersebut tentu memberatkan bagi Indonesia karena Indonesia merupakan salah satu produsen terbesar rokok kretek (clove cigarettes).

Sengketa terhadap ketentuan rokok cengkeh AS telah diajukan ke Dispute Settlement Body (DSB)-WTO dan memakan proses yang cukup lama, meliputi: permintaan konsultasi (7 April 2010), laporan Panel (2 September 2011), dan laporan Appellate Body (4 April2012). Pada tanggal 3 Oktober 2014, Indonesia dan AS telah menotifikasikan ke DSB bahwa kedua belah pihak telah mencapai kesepakatan bersama sehingga DSB tidak perlu mengeluarkan keputusan final pada kasus tersebut (WTO, 2014).

Direktur Jenderal Direktorat Jenderal Kerja Sama Perdagangan Internasional (DJKPI), Bachrul Chairi, menyebutkan bahwa keuntungan yang didapat Indonesia melalui penyelesaian di luar WTO lebih signifikan jika dibanding upaya langkah tindakan pembalasan (retaliasi) senilai USD 55 juta dari total impor Indonesia dari Amerika AS (DJKPI, 2014). Beberapa kesepakatan lain yang akan menguntungkan Indonesia adalah pemerintah AS akan memberikan tambahan fasilitas Generalized System of Preferences (GSP) yang melebihi dari nilai batas tertentu selama lima tahun berikutnya dan akan mempertimbangkan permintaan atas produk ekspor lainnya dari Indonesia. AS juga tidak akan mengganggu akses pasar produk cigars dan cigarillos buatan Indonesia di pasar AS sampai ada pengaturan lebih lanjut yang tidak akan bersifat arbitrary atau discriminative (membeda-bedakan produk secara merugikan) (DJKPI, 2014).

Sebagai akibat dari implementasi Tobacco Control Act (2009), Indonesia tidak lagi melakukan ekspor rokok kretek ke AS mulai tahun 2010 sebagaimana terlihat pada Tabel 3 dengan menggunakan mirror data GTIS (impor AS). Data BPS dalam level 10 digit tidak merinci ekspor rokok yang mengandung cengkeh, berbeda dengan data impor Bea Cukai AS (GTIS) yang mencatat impor rokok yang mengandung cengkeh. Meskipun mengalami penurunan nilai ekspor rokok Indonesia ke AS akibat Tobacco 
Control Act, namun penurunan tersebut tidak terlalu dalam karena adanya

peningkatan ekspor produk rokok yang lainnya, terutama cerutu.

Tabel 3. Impor Rokok AS dari Indonesia, CIF (Juta USD)

\begin{tabular}{lcccr}
\hline \multicolumn{1}{c}{ Keterangan } & $\mathbf{2 0 0 6}$ & $\mathbf{2 0 0 9}$ & $\mathbf{2 0 1 0}$ & $\mathbf{2 0 1 3}$ \\
\hline Rokok Kretek/Cengkeh & 10,49 & 7,65 & - & - \\
Rokok Selain Kretek & 0,53 & 0,03 & - & 0,04 \\
Cerutu & 0,20 & 5,15 & 11,86 & 14,38 \\
Total Rokok & $\mathbf{1 1 , 2 2}$ & $\mathbf{1 2 , 8 3}$ & $\mathbf{1 1 , 8 6}$ & $\mathbf{1 4 , 4 3}$ \\
\hline $\begin{array}{l}\text { : } \\
\text { GTIS (2015b), diolah }\end{array}$ & $\begin{array}{l}\text { Rokok Kretek (HS 240220.10.00); Rokok selain Kretek (Produk dalam cakupan } \\
\text { HS 240220 selain HS 240220.10.00); dan Cerutu (HS 240210). }\end{array}$
\end{tabular}

2. Australia: Competition and Consumer (Tobacco) Information Standard 2011

Pada tanggal 1 Januari 2012, Pemerintah Australia mengesahkan Competition and Consumer (Tobacco) Information Standard 2011 yang berlaku efektif 1 Desember 2012 dalam rangka mengurangi daya tarik produk tembakau kepada konsumen, terutama usia muda. Ketentuan tersebut intinya berisi bahwa seluruh produk tembakau yang dijual dan diedarkan di Australia harus dalam kemasan yang homogen (plain packaging). Selain kebijakan tersebut, cukai rokok di Australia dinaikkan masing-masing sebesar $12,5 \%$ pada 1
Desember 2013, 1 September 2014, 1 September 2015, dan 1 September 2016 (Department of Health, Australia, 2014).

Penerapan Tobacco Plain Packaging di Australia tidak menyebabkan penurunan ekspor rokok Indonesia ke pasar tersebut. Sebaliknya, data BPS (2015b) menunjukkan bahwa nilai ekspor rokok Indonesia di tahun 2013 sebesar USD 2,5 juta, meningkat $1.079 \%$ dibandingkan 2012 yang hanya USD 215 ribu. Volume ekspor rokok Indonesia ke Australia juga melonjak signifikan dari 16,6 ton (2012) menjadi 188,7 ton (2013) dan 234 ton (2014) (Tabel 4). 
Tabel 4. Ekspor Rokok Indonesia ke Australia, 2010-2014

\begin{tabular}{|c|c|c|c|c|c|c|}
\hline HS & Keterangan & 2010 & 2011 & 2012 & 2013 & 2014 \\
\hline \multicolumn{7}{|c|}{ Nilai Ekspor (Ribu USD) } \\
\hline 240210 & $\begin{array}{l}\text { Cerutu, cheroot dan cerutu } \\
\text { kecil, mengandung tembakau }\end{array}$ & 26,12 & 65,84 & 7,42 & 29,19 & 21,80 \\
\hline \multirow[t]{2}{*}{240220} & $\begin{array}{l}\text { Sigaret mengandung } \\
\text { tembakau }\end{array}$ & 47,65 & 33,83 & 208,38 & $2.515,57$ & $3.029,26$ \\
\hline & Total nilai & 73,78 & 99,66 & 215,80 & 2.544 .76 & $3.051,06$ \\
\hline \multicolumn{7}{|c|}{ Volume Ekspor (Ton) } \\
\hline 240210 & $\begin{array}{l}\text { Cerutu, cheroot dan cerutu } \\
\text { kecil, mengandung tembakau }\end{array}$ & 3,19 & 3,47 & 0,14 & 1,44 & 0,38 \\
\hline \multirow[t]{2}{*}{240220} & $\begin{array}{l}\text { Sigaret mengandung } \\
\text { tembakau }\end{array}$ & 2,48 & 2,64 & 16,44 & 187,27 & 234,03 \\
\hline & Total volume & 5,66 & 6,11 & 16,57 & 188,71 & 234,41 \\
\hline
\end{tabular}

Sumber: BPS (2015b), diolah

Darikasus hambatan non-tarif ekspor rokok Indonesia di pasar AS tahun 2009 berupa larangan rokok kretek/cengkeh dan di pasar Australia tahun 2012 berupa penerapan plain packaging, dapat ditarik pelajaran bahwa kebijakan tersebut tidak terlalu berdampak pada ekspor rokok Indonesia secara keseluruhan karena kedua negara tersebut bukanlah merupakan tujuan utama ekspor rokok Indonesia. Ekspor rokok ke AS hanya sedikit mengalami kontraksi karena berhentinya ekspor rokok kretek, namun mampu dikompensasi dengan peningkatan ekspor rokok jenis cerutu. Sementara itu, ekspor rokok ke Australia mengalami peningkatan yang signifikan meskipun telah diterapkannya ketentuan plain packaging.

Temuan Empiris Tobacco Control dan Re-ekspor Singapura terhadap Ekspor Rokok Indonesia

Hasil estimasi fungsi konsumsi dengan menggunakan log-log linier sebagaimana ditampilkan pada Tabel 5 diperoleh koefisien pendapatan riil bertanda positif $(0,37)$ dan signifikan pada level $10 \%$ yang mengindikasikan bahwa rokok merupakan barang normal. Temuan ini sejalan dengan meta-analisis yang dilakukan Andrews \& Franke (1991) menggunakan 48 studi yang menghasilkan elastisitas pendapatan rata-rata tertimbang sebesar 0,36 dan signifikan. Estimasi elastisitas pendapatan pada permintaan rokok di Australia yang dilakukan Davidson \& de Silva (2014) juga menunjukkan 
koefisien positif dan signifikan $(0,086$ hingga 0,119 ). Sementara itu, penelitian Kenkel, Schmeiser, \& Urban (2014) di AS menunjukkan bahwa saat ini rokok bukan merupakan barang inferior yang salah satu penyebabnya adalah peningkatan pendapatan pada masyarakat kelas bawah karena transfer pemerintah. Untuk kasus Singapura, penyebab peningkatan pendapatan berpengaruh positif terhadap konsumsi rokok kemungkinan dikarenakan peningkatan smoking prevalence pada penduduk usia muda antara umur 18 hingga 29 tahun sebagaimana hasil National Health Survey, yaitu dari 12,3\% di tahun 2004 menjadi $16,3 \%$ di tahun 2010 (MOH, 2004 dan 2010). Menurut Yin (2010), perokok usia muda di Singapura umumnya dipengaruhi oleh tingginya kelaziman konsumsi rokok pada jaringan sosial mereka ${ }^{6}$.

Variabel harga ritel riil tidak signifikan mempengaruhi permintaan rokok Singapura. Hal ini bisa jadi mengindikasikan bahwa peningkatan harga jual rokok masih tetap terjangkau oleh konsumen karena tingkat pendapatan yang relatif tinggi? Sementara itu, meskipun varibel cukai memiliki tanda koefisien negatif namun secara statistik tidak signifikan. Menurut Kuen \& Yee (2015), rokok selundupan di Singapura lebih murah setengahnya dibandingkan harga ritel rokok yang beredar secara resmi. Bahkan, Bea Cukai Singapura menangkap penyelundup rokok dalam setiap satu atau dua bulan sekali. Meskipun harga rokok dianggap sudah tinggi, namun para perokok masih dapat mencari jalan lain untuk mendapatkan rokok murah dalam rangka memuaskan keinginannya. Keberadaan rokok ilegal melemahkan dampak yang diharapkan dari tingginya pajak dan harga rokok. Sementara itu, justru pajak barang umum (GST) berpengaruh negatif dan signifikan terhadap konsumsi rokok. Hal ini mengindikasikan bahwa penduduk Singapura lebih mengutamakan barang kebutuhan yang lain dibandingkan untuk membeli rokok karena kenaikan GST berlaku untuk semua barang dan jasa yang akan dikonsumsi.

Kebijakan pengendalian tembakau non-harga, baik berupa kewajiban label maupun pelarangan misleading descriptor, tidak signifikan berpengaruh negatif terhadap konsumsi rokok di Singapura. Temuan ini serupa dengan hasil penelitian Ross \& Al-Sadat (2007) yang menggunakan sampel Malaysia. Kemungkinan penyebab kenapa kebijakan pengendalian tembaku Singapura tidak berpengaruh signifikan karena kebijakan yang dikeluarkan selama tahun 2004 hingga 2014 merupakan kebijakan yang sifatnya penyempurnaan (incremental). Kebijakan fundamental pengetatan konsumsi tembakau telah dilakukan Singapura pada tahun 1970an. Kemungkinan lain adalah kita tidak bisa mengharapkan kebijakan non-harga mengurangi konsumsi rokok apabila

Studi Picco et al. (2012) menunjukkan bahwa perokok di Singapura umumnya merupakan usia muda, laki-laki, berbangsa Melayu, dan memiliki tingkat pendidikan rendah

Isu keterjangkauan harga rokok (affordability of cigarettes) dapat dilihat lebih lanjut pada Blecher dan van Walbeek (2004) serta Kostova et al. (2014). 
kebijakan pajak cukai yang secara langsung berdampak pada daya beli tidak efektif menurunkan konsumsi rokok ${ }^{8}$.

Konsumsi rokok penduduk usia muda bisa saja terus meningkat apabila implementasi kebijakan non-cukai atau pengawasannya lemah. Bisa juga, kebijakan pembatasan merokok di tempat umum menghambat perokok untuk merokok di tempat tersebut, namun bukan berarti konsumsi rokoknya berkurang (merokok di tempat lain). Sebagaimana hasil temuan studi Wilson et al. (2012), masing-masing instrumen kebijakan pengendalian tembakau memiliki dampak yang beragam. Kebijakan larangan merokok di tempat umum dan kampanye antitembakau di media masa berdampak moderat terhadap penurunan smoking prevalence. Sementara itu, label peringatan kesehatan dan larangan iklan dan sponsorship tidak ditemukan cukup bukti mengurangai smoking prevalence.

Untuk mengetahui apakah permintaan rokok di Singapura mengikuti myopic addictive behavior atau rational addictive behavior, maka dimasukkan variabel konsumsi masa lalu (Cons $\mathrm{t}_{\mathrm{t}-1}$ ) dan konsumsi masa depan (Cons $s_{t+1}$ ). Hasil regresi menunjukkan bahwa konsumsi masa lalu berkoefisien positif namun tidak signifikan secara statistik ${ }^{9}$, sedangkan konsumsi masa depan berkoefisien negatif dan signifikan pada level $1 \%$. Hal ini mengindikasikan bahwa perilaku perokok di Singapura mengikuti hipotesis rational addictive behavior yang umum dijumpai di negara-negara maju dimana penduduknya sebagian besar berpendidikan tinggi dan memiliki pemahaman yang lebih baik mengenai pola hidup yang sehat. Hal ini didukung dengan koefisen negatif dan signifikan pada variabel jumlah warga yang merokok (SmRes). Jumlah warga Singapura yang merokok memang terus bertambah, namun jumlah yang dikonsumsi semakin berkurang yang mengindikasikan mereka mempertimbangkan efek jangka panjang merokok di masa datang. Sebaliknya, semakin banyak jumlah imigran di Singapura semakin tinggi permintaan konsumsi rokok. Perlu ditambahkan bahwa jumlah imigran di Singapura baik yang dalam rangka bekerja maupun belajar mencapai hampir 30\% dari total populasi Singapura (Department of Statistics Singapore, 2015).

\footnotetext{
WHO (2003) menyimpulkan bahwa peningkatan harga produk tembakau (cukai) merupakan instrumen yang paling efektif menurunkan konsumsi rokok dibandingkan instumen kebijakan lainnya (larangan iklan dan promosi, pembatasan konsumsi merokok ditempat publik maupun usia muda, kampanye pendidikan komsumen, maupun terapi berhenti merokok). Kebijakan peningkatan harga rokok semakin efektif jika dikombinasikan dengan peningkatan harga pada produk tembakau tanpa asap (Adhikari et al., 2012)

$9 \quad$ Temuan ini kurang mendukung penelitian Ahmed dan Vaziri (2014) bahwa konsumsi rokok masa lalu berpengaruh positif dan signifikan terhadap konsumsi rokok saat ini.
} 
Tabel 5. Hasil Estimasi Konsumsi Rokok di Singapura

\begin{tabular}{lrr}
\hline \multicolumn{1}{c}{ Variabel Penjelas } & Koefisien & t-statistik \\
\hline Pendapatan riil $(I n c)$ & $0,373^{*}$ & 2,053 \\
Harga riil $(P)$ & 0,327 & 0,506 \\
Cukai $(E x c)$ & $-0,212$ & $-0,274$ \\
GST & $-0,721^{* * *}$ & $-3,555$ \\
Kewajiban label (D_label) & 0,099 & 1,717 \\
Pelarangan misleading descriptor (D_misdesc) & $-0,045$ & $-1,163$ \\
Konsumsi masa lalu (Cons t-1 $\left._{1}\right)$ & 0,055 & 0,819 \\
Konsumsi masa depan $\left(\right.$ Cons $\left._{\mathrm{t+1}}\right)$ & $-0,452^{* * *}$ & $-4,674$ \\
Jumlah warga yang merokok $($ SmRes) & $-0,754^{* *}$ & $-2,380$ \\
Jumlah imigran $($ NonRes) & $1,574^{* * *}$ & 2,883 \\
Triwulan II (D_q2) & $-0,103^{* * *}$ & $-3,153$ \\
Konstanta & 0,874 & 0,271 \\
$\mathrm{R}^{2}=0,905$ & & \\
\hline
\end{tabular}

Sumber: Hasil olah data

Keterangan:

* Signifikan pada level 10\%; ** Signifikan pada level 5\%; *** Signifikan pada level $1 \%$

D_q2 merupakan variabel dummy dengan nilai 1 (satu) pada kuartal II dan 0 (nol) untuk kuartal lainnya dengan tujuan mengisolasi adanya pola musiman pada data yang digunakan (seasonality)

Hasil regresi 2SLS dengan terutama untuk rokok jenis kretek memasukkan persamaan konsumsi (mengandung cengkeh).

ke dalam salah satu variabel penjelas pada persamaan permintaan ekspor rokok Indonesia dapat dilihat pada Tabel 6. Konsumsi rokok dan ekspor rokok Singapura keduanya berpengaruh positif, namun hanya ekspor yang signifikan pada level 5\%. Dengan asumsi faktor lain konstan, peningkatan ekspor rokok Singapura sebesar $10 \%$ dalam rangka memenuhi permintaan dunia turut meningkatkan ekspor rokok Indonesia sebesar $7,5 \%$. Hal ini mengindikasikan bahwa ekspor rokok Indonesia ke Singapura lebih banyak dipengaruhi oleh aktivitas re-ekspor rokok yang dilakukan oleh Singapura daripada konsumsi rokok domestiknya,

Berdasarkan data GTIS (2015a), rata-rata impor rokok kretek Singapura dari Indonesia periode 2012-2014 sebesar 4.076 ton/tahun sedangkan ekspor rokok kretek Singapura ke dunia untuk periode yang sama mencapai 4.089 ton/tahun. Hal ini menegaskan hasil analisis sebelumnya bahwa rokok Indonesia banyak diekspor kembali oleh Singapura melalui jaringan perusahaan multinasional. Dengan kata lain, Singapura bukanlah merupakan pasar akhir terbesar bagi produk rokok Indonesia, meskipun Singapura salah merupakan tujuan ekspor rokok Indonesia berdasarkan data BPS (2015a). 
Tabel 6. Hasil Estimasi Permintaan Ekspor Rokok Indonesia

\begin{tabular}{lrr}
\hline \multicolumn{1}{c}{ Variabel Penjelas } & Koefisien & t-statistik \\
\hline Ekspor rokok $(X \sin )$ & $0,749^{* *}$ & 2,140 \\
Konsumsi domestik (Cons) & 0,479 & 1,665 \\
Nilai tukar riil (REER) & $-1,985$ & $-1,123$ \\
Dummy krisis (Dcris) & $-0,052$ & $-0,197$ \\
AR(1) & $0,539^{* * *}$ & 3,359 \\
Konstanta & 6,688 & 0,729 \\
$\mathrm{R}^{2}=0,576$ & & \\
\hline
\end{tabular}

Sumber: Hasil olah data

Keterangan:

** Signifikan pada level $5 \%$; ${ }^{* * *}$ Signifikan pada level $1 \% A R(1)$ merupakan autoregressive dengan lag 1 (satu).

\section{KESIMPULAN DAN REKOMENDASI KEBIJAKAN}

Kebijakan plain packaging yang diterapkan oleh Singapura diperkirakan tidak akan berdampak signifikan terhadap ekspor rokok Indonesia. Hal ini disebabkan oleh: Pertama, kebijakan tobacco control non-harga yang dilakukan Pemerintah Singapura tidak berpengaruh signifikan terhadap pengurangan konsumsi rokok domestik. Justru pendapatan riil menjadi salah satu faktor utama yang mendorong terjadinya peningkatan konsumsi rokok. Selain itu, meningkatnya smoking prevalence pada penduduk Singapura usia muda dan banyaknya warga pendatang masih mendukung perkembangan pasar rokok di Singapura. Kedua, Singapura bukanlah merupakan pasar akhir yang utama bagi produk rokok Indonesia. Permintaan ekspor rokok
Indonesia lebih banyak dipengaruhi oleh re-ekspor rokok yang dilakukan Singapura daripada konsumsi rokok domestiknya.

Apabila Singapura pada akhirnya menerapkan ketentuan plain packaging, Indonesia harus secara aktif melakukan advokasi melalui mekanisme Dispute Settlement Body (DSB)-WTO maupun dengan negosiasi bilateral. Meskipun sengketa plain packaging dengan Australia belum ada keputusan akhir dari DSB, namun kemenangan Indonesia dalam kasus pelarangan rokok kretek di AS dapat menjadi pelajaran berharga bahwa meskipun rokok kretek Indonesia tidak lagi masuk ke pasar AS tetapi ekspor rokok Indonesia untuk jenis cerutu ke AS meningkat pesat serta mendapatkan kompensasi perdagangan dan investasi dari AS yang lebih besar dari nilai produk ekspor Indonesia yang dipersengketakan. 


\section{UCAPAN TERIMA KASIH}

Terima kasih atas masukan dari para reviewer sehingga menyempurnakan naskah ini. Terima kasih pula kepada rekan saya, Dhanie Nugroho, yang telah membantu penulis untuk mendapatkan literatur yang relevan dan mutakhir.

\section{DAFTAR PUSTAKA}

Adhikari, B. B., Zhen, C., Kahende, J. W., Goetz, J., \& Loomis, B. (2012). Price Responsiveness of Cigarette Demand in US: Retail Scanner Data (1994-2007). Economics Research International, Vol. 2012, pp. 1-10. doi:10.1155/2012/148702

Ahmed, S. M. \& Varizi, K. (2014). Price Elasticity of Demand for Cigarettes: The Case of Sweden. Master Degree Project. Sweden: Högskolan Dalarna.

Andrews, R. L. \& Franke, G. R. (1991). The Determinants of Cigarette Consumption. Journal of Public Policy and Marketing, Vol. 10 (1), pp. 81-100.

Assunta, M. \& Chapman, S. (2004). The World's Most Hostile Environment: How the Tobacco Industry Circumvented Singapore's Advertising Ban. Tobacco Control 2004, Vol. 13 (2), pp. li51-ii57. doi:10.1136/tc.2004.008359

Badan Pusat Statistik (BPS) (2015a). Data Ekspor Rokok Indonesia ke Singapura

Badan Pusat Statistik (BPS) (2015b). Data Ekspor Rokok Indonesia ke Australia

Becker, G. \& Murphy, K. M. (1988). A Theory of Rational Addiction. The Journal of Political Economy, Vol. 96 (4), pp. 675-700.

Becker, G., Grossman, M., \& Murphy, K. M. (1994). An Empirical Analysis of Cigarette Addiction. The American Economic Review, Vol. 84 (3), pp. 396-418.

Blecher, E. H. \& van Walbeek, C. P. (2004). An International Analysis of Cigarette Affordability. Tobacco Control, Vol. 13 (4), pp. 339-346.
British American Tobacco (BAT) (2009, Juni 17). British American Tobacco acquires control of Indonesia's Bentoel. Diunduh tanggal 11 November 2015 dari http://www.bat.com/group/sites/ UK__9D9KCY.nsf/vwPagesWebLive/ DO7T3LEJ?opendocument

Business World (2013, April 12). Why is Demand for Cigarettes Inelastic? Diunduh tanggal 9 Juli 2015 dari http://research.bworldonline. com/popular-economics/story. php?id=114\&title=Why-is-demand-forcigarettes-inelastic?\#

Chaloupka, F. J. (1991). Rational Addictive Behavior and Cigarette Smoking. Journal of Political Economy, Vol. 99 (4), pp. 722-742.

Chaloupka, F. J. \& Tauras, A. (2011). The Demand for Cigarettes in Ireland. Diunduh tanggal 10 Juli 2015 dari http:// www.hse.ie/eng/health/hl/change/ QUIT/demandforcigarettes2011.pdf

Chen, Y. \& Xing, W. (2011). Quantity, Quality, and Regional Price Variation of Cigarettes: Demand Analysis Based on a Household Survey in China. China Economic Review, Vol. 22 (2), pp. 221-232.

Czubek, M. \& Johal, S. (2010). Cigarette Consumption in the UK. HMRC Working Paper No. 9. Diunduh tanggal 7 Juli 2015 dari https://www.gov.uk/ government/uploads/system/uploads/ attachment_data/file/331580/cigconsumption-uk.pdf

Davidson, S., \& de Silva, A. (2014). The Plain Truth about Plain Packaging: An Econometric Analysis of the Australian 2011 Tobacco Plain Packaging Act. Agenda: A Journal of Policy Analysis and Reform, Vol. 21 (1), pp. 27-43.

Department of Health, Australia (2014). Introduction of Tobacco Plain Packaging in Australia. Diunduh tanggal 7 Juli 2015 dari http:// www.health.gov.au/internet/main/ publishing.nsf/Content/tobacco-plain

Department of Statistics Singapore. (2015). Yearbook of Statistics Singapore 2015. 
Diunduh tanggal 27 Oktober 2015 dari http://www.singstat.gov.sg/docs/ default-source/default-documentlibrary/publications/publications_and papers/reference/yearbook_ $2015 /$ yos2015.pdf

DirektoratJenderalKerjaSamaPerdagangan Internasional, Perdagangan RI (DJKPI). (2014). Indonesia-AS Sepakat Hentikan Kasus Rokok Kretek. Diunduh tanggal 23 Juli 2015 dari http://ditjenkpi. kemendag.go.id/website_kpi/index. php? module=news_detail\&news_ content_id=1511\&detail=true

Forbes (2013, September 6). Big Tobacco Takes Its Last Drag As Economic Change Looms. Diunduh tanggal 9 Juli 2015 dari http://www.forbes.com/sites/ thestreet/2013/09/06/big-tobaccotakes-its-last-drag-as-economicchange-looms/

Gallet, C. \& List, J. (2003). Cigarette Demand: A Meta-Analysis of Elasticities. Health Economics, Vol. 12 (10), pp. 821-35.

Global Trade International Services (GTIS) (2015a). United States Import Statistics from Indonesia on Cigars, Cheroots, Cigarillos And Cigarettes.

Global Trade International Services (GTIS) (2015b). Singapore Export and Import Statistics on Cigarettes Containing Tobacco.

Hidayat, B., \& Thabrany, H. (2011). Are Smokers Rational Addicts? Empirical Evidence from the Indonesian Family Life Survey. Harm Reduction Journal, Vol. 8 (6). doi: 10.1186/1477-7517-8-6

Hill, R. C., W. E. Griffiths, W. E., \& G. C. Lim, G. C. (2012). Principles of Econometrics. Fourth Edition, International Student Version. New York: John Wiley and Sons.

International Agency for Research on Cancer (IARC). (2011). IARC Handbooks of Cancer Prevention, Tobacco Control, Vol. 14: Effectiveness of Tax and Price Policies for Tobacco. Lyon, France: IARC.
International Tax and Investment Center \& Oxford Economics (2014). Asia-14 Illicit Tobacco Indicator 2013. Diunduh tanggal 15 Juli 2015 dari http://www. pmi.com/eng/tobacco_regulation/ illicit_trade/Documents/Asia-14\%20 Illicit\%20Tobacco $\% 20$ Indicator $\% 20$ 2013.pdf

Japan Tobacco International (JTI) (2015). JTI Russia. Diunduh tanggal 11 November 2015 dari http://www.jti. com/our-company/where-we-operate/ europe/russia/english/overview/

Kenkel, D. S., Schmeiser, M. D., \& Urban, C. (2014). Is Smoking Inferior? Evidence from Variation in the Earned Income Tax Credit. The Journal of Human Resources, Vol. 49 (4), pp. 1094-1120. doi:10.3368/jhr.49.4.1094

Kostova, D., Chaloupka, F. J., Yurekli, A., Ross, H., Cherukupalli, R., Andes, L., \& Asma, S. (2014). A Crosscountry Study of Cigarette Prices and Affordability: Evidence from the Global Adult Tobacco Survey. Tobacco Control, Vol. 23(1), pp.1-8. doi:10.1136/ tobaccocontrol-2011-050413

Kuen, M. A. \& Yee, F. W. (2015). Effectiveness of the Smoking Policies in Singapore (National Tobacco Control Programme) to Reduce Smoking Prevalence. PostTrip Report: International Experience Fund. Hong Kong: City University.

Liu, H., Rizzo, J. A., Sun, Q., \& Wu, F. (2015). How Do Smokers Respond to Cigarette Taxes? Evidence from China's Cigarette Industry. Health Economics, Vol. 24 (10), pp. 13141330. doi: $10.1002 /$ hec.3084

Ministry of Finance, Singapore (MOF). (2015). Goods and Services Tax. Diunduh tanggal 2 Oktober 2015 dari http://www.mof.gov.sg/Policies/TaxPolicies/Goods-and-Services-Tax

Ministry of Health, Singapore $(\mathrm{MOH})$. (2004). National Heath Survey 2004. Diunduh tanggal 21 Oktober 2015 dari https://www.moh.gov.sg/content/moh web/home/Publications/Reports/2005/ national_health_survey2004.html 
Ministry of Health, Singapore (MOH). (2010). National Heath Survey 2010. Diunduh tanggal 21 Oktober 2015 dari https://www.moh.gov.sg/content/moh_ web/home/Publications/Reports/2011/ national_health_survey2010.html

Ministry of Health, Singapore (MOH). (2015). Embargoed Until After Delivery of MOH Committee of Supply Debate 2015. Diunduh tanggal 14 Juli 2015 dari https://www.moh.gov.sg/ content/moh_web/home/pressRoom/ pressRoomltemRelease/2015/ ministry-of-health-budgetinitiatives-2015/_jcr_content/ entryContent/download_3/file.res/ Factsheet $\% 20$ on $\% 20 \mathrm{Healthy} \% 20$ Living \% 20 Everyday $\% 20$ - \% 20 Tobacco\%20Control\%20(Mar\%20 2015).pdf

Mushtaq, N., Mushtaq, S. \& Beebe, L. A. (2011). Economics of Tobacco Control in Pakistan: Estimating Elasticities of Cigarette Demand. Tobacco Control, Vol. 20 (6), pp. 431-435. doi: 10.1136/ tc. 2010.040048

Nguyen, L., Rosenqvist, G., \& Pekurinen, M. (2012). Demand for Tobacco in Europe: An Econometric Analysis of 11 Countries for the PPACTE Project. Helsinki, Finland: National Institute for Health and Welfare.

Philip Morris International (PMI) (2005, Maret 14). Philip Morris International Inc. (PMI) announces agreement to purchase $40 \%$ stake in PT HM Sampoerna Tbk, Indonesia's third largest tobacco company. Diunduh tanggal 11 November 2015 dari http://www.pmi.com/ eng/media_center/press_releases/ Pages/200503140000.aspx\#

Picco, L., Subramaniam, M., Abdin, E., Vaingankar, J. A., \& Chon, S. A. (2012). Smoking and Nicotine Dependence in Singapore: Findings from a CrossSectional Epidemiological Study. Annals of the Academy of Medicine Singapore, Vol. 41 (8), pp. 325-334.
Ross, H. \& Al-Sadat, N. A. M. (20075). Demand Analysis of Tobacco Consumption in Malaysia. Nicotine \& Tobacco Research. The Collaborative Funding Program for Southeast Asia Tobacco Control Research. Southeast Asia Tobacco Control Alliance (SEATCA), Vol. 9 (11), pp. 1163-1169. doi:10.1080/14622200701648433

Scollo, M. M. \& Winstanley, M. H. (2012). Tobacco in Australia: Facts and Issues. 4th ed. Melbourne: Cancer Council Victoria. Diunduh tanggal 9 Juli 2015 dari http://www.tobaccoinaustralia.org. au

U.S. Food and DrugAdministration (USFDA). (2015). Tobacco Control Act. Diunduh tanggal 7 Juli 2015 dari http://www. fda.gov/TobaccoProducts/Guidance ComplianceRegulatoryInformation/ ucm246129.htm

U.S. Government Publishing Office (US GPO). (2009). Family Smoking Prevention Tobacco Control Act. Public Law 111-31. Diunduh tanggal 10 Juli 2015 dari http://www.gpo. gov/fdsys/pkg/PLAW-111 publ31/pdf/ PLAW-111publ31.pdf

Wilson, L. M., Avila, T. E., Chander, G., Hutton, H. E., Odelola, O. A., Elf, J. L., Heckman-Stoddard, B. M., Bass, E. B., Little E. A., Haberl, E. B., \& Apelberg, B. J. (2012). Impact of Tobacco Control Interventions on Smoking Initiation, Cessation, and Prevalence:

A Systematic Review. Journal of Environmental and Public Health, Vol. 2012. doi:10.1155/2012/961724

World Bank. (1999). Curbing the epidemic: governments and the economics of tobacco control. Diunduh tanggal 13 Juli 2015 dari http:// documents.worldbank.org/curated/ en/1999/05/437174/curbing-epidemicgovernments-economics-tobaccocontrol

World Health Organization (WHO). (2003). Which are the Most Effective and Cost- 
Effective Interventions for Tobacco Control? Diunduh tanggal 13 Juli 2015 dari http://www.euro.who.int/_data/ assets/pdf_file/0004/74722/E82993. pdf

World Health Organization (WHO). (2015). Singapore Smoking Prevalence Tobacco. Diunduh tanggal 7 Juli 2015 dari www.who.int/tobacco/media/en/ Singapore.pdf
WTO (2014). DS406: United States Measures Affecting the Production and Sale of Clove Cigarettes. Diunduh tanggal 10 Juli 2015 darihttps://www. wto.org/english/tratop_e/dispu_e/ cases_e/ds406 e.htm\#bkmk406abr

Yin, C. L. (2010). The Young Singaporean Smokers: Factors Influencing Smoking Behaviour. PhD Thesis. Singapore: Sociology Department, National University of Singapore. 